This PDF is a selection from a published volume from the National Bureau of Economic Research

Volume Title: Research Findings in the Economics of Aging

Volume Author/Editor: David A. Wise, editor

Volume Publisher: The University of Chicago Press

Volume ISBN: 0-226-90306-0

Volume URL: http://www.nber.org/books/wise08-1

Conference Dates: May 10-13, 2007

Publication Date: February 2010

Chapter Title: The Education Gradient in Old Age Disability

Chapter Author: David M. Cutler, Adriana Lleras-Muney

Chapter URL: http://www.nber.org/chapters/c8194

Chapter pages in book: $(101-120)$ 


\title{
The Education Gradient in Old Age Disability
}

\author{
David M. Cutler and Adriana Lleras-Muney
}

Disability among older adults has a clear socioeconomic gradient. Nearly half of elderly people with less than a high school degree report some difficulty caring for themselves, whereas only about a quarter of college graduates report that they are disabled. The lower disability rate among the better educated results in substantial differences in health and medical spending. Of disabled people, 10 percent live in a nursing home. ${ }^{1}$ In addition, disabled people spend as much as five times more on medical care than the nondisabled (Chernew et al. 2005), and mortality rates are significantly higher for the disabled (Manton 1988). Disability rates have been falling in the United States (Cutler 2001). Understanding why education is related to disability and whether changes in education have contributed to disability declines is thus a central policy concern.

There are many theories about the link between education and disability, ranging from childhood conditions that affect both education and disability, occupational differences in the working years, differential health behaviors, differential access to medical care, and differential living situations as a senior. In this chapter, we examine this range of theories. Our empirical analysis is straightforward: we relate disability to education first with only basic demographic controls, and then with a series of controls for life course

David M. Cutler is the Otto Eckstein Professor of Applied Economics at Harvard University and a research associate of the National Bureau of Economic Research. Adriana Lleras-Muney is an associate professor of economics at the University of California, Los Angeles, and a faculty research fellow of the National Bureau of Economic Research.

This chapter was prepared for the NBER Conference on the Economics of Aging, May 2007. We are grateful to Doug Norton for research assistance, to Anne Case and conference participants for helpful comments, and to the National Institutes on Aging and the Lasker Foundation for research support.

1. This reflects authors' calculations from the 2004 Medicare Current Beneficiary Survey. 
events. We see how each of these controls affects the education gradient in disability.

Our data come from the Health and Retirement Study (HRS). Because the HRS is focused on the elderly, our sample sizes are large; we have 9,157 observations in the 2002 survey. With the exception of measures of lifetime occupation, our control variables are also very good. Three factors emerge from our results as particularly associated with the education gradient in disability. The first is health behaviors. Better educated people are significantly less likely to smoke than are less educated people; they are also less obese. Smoking and obesity are both strongly related to disability, and explain a good part of the education effect. Our results show that about one-third of the education gradient in disability is associated with differential health behaviors. Another third is explained by differences in lifetime occupation. Finally, differential rates of medical conditions explain another fifth of the education gradient in disability. Stroke, heart disease, and chronic conditions such as diabetes and arthritis are highly related to disability. Less educated people are more likely to have suffered from these conditions, partly as a result of their greater propensity to smoke and be obese. All told, differences in occupation, health behaviors, and their disease consequences explain essentially all of the differences between those with high school degrees and college graduates. However, the factors we analyze can only explain about 55 percent of the differences in disability rates between those with a high school degree and high school dropouts. Interestingly, childhood conditions, use of preventive care after age sixty-five, and living arrangements after age sixty-five do not explain a large share of the education gradient in disability.

We present these findings, and also note their limitations. Most importantly, we do not explain why better educated people have healthier lifestyles. To what extent is that nature, nurture, or their interaction? What in nurture explains these differences? Our ongoing work focuses on this issue (Cutler and Lleras-Muney 2007a, 2007b), but we do not address it here. Nevertheless, these results suggest that the increased education of recent cohorts will result in lower disability rates in the future and that if lowering education gradients is the policy objective, then efforts should concentrate on modifying the health behaviors of less educated individuals.

Our chapter is structured as follows. The first section discusses measures of disability and shows the education gradient in disability. The second section elucidates theories for the education gradient. The third section presents our empirical results. The last section concludes.

\subsection{The Education Gradient in Disability}

To measure population disability, we use data from the 2002 Health and Retirement Study. Since the HRS is longitudinal, data from any year should 
be similar. The 2002 data are recent, and can be linked to extensive prior information. In addition, the initial HRS sample (1992 and 1993) was of the community-dwelling population only. By 2002, however, many of those people will have moved into an institution, and so our sample is nationally representative. ${ }^{2}$ We consider people age sixty-five and older. We focus on the elderly to avoid reporting issues associated with collection of Disability Insurance. Other surveys of disability are also focused on the elderly (e.g., the National Long-Term Care Survey, and the Medicare Current Beneficiary Survey), making our results comparable with previous studies. The 2002 survey contains complete information on 9,155 elderly people.

Disability refers to whether a person can function independently in society (Verbrugge 1994). Functioning is both physical and cognitive; an ideal measure picks up both. In practice, most researchers use a measure of disability defined by Nagi (1965) in the 1960s: whether a person has impairments in physical Activities of Daily Living (ADLs) or social Instrumental Activities of Daily Living (IADLs). A typical set of ADL impairments includes difficulty eating, bathing, dressing, walking across a room, and getting in and out of bed. Typical IADL impairments include difficulty using a telephone, taking medication, managing money, shopping for groceries, and preparing meals. The ADL questions in the HRS are as follows: "Here are a few more everyday activities. Please tell me if you have any difficulty with these because of a physical, mental, emotional, or memory problem. Again exclude any difficulties you expect to last less than three months. Because of a health or memory problem do you have any difficulty with. ..." Possible answers are "yes," "no," "can't do," and "don't do." We define a disability as it is usually done in the literature: an individual is coded as disabled if he answers yes or that he cannot or does not do any of the ten activities.

We examine the link between education and disability. ${ }^{3}$ Consistent with most of the literature, we group education into four categories: less than a high school degree, high school graduate, some college, and a college degree or more. In our sample, 28 percent of people have less than a high school degree, 36 percent have exactly a high school education, 18 percent have some college, and 18 percent completed college.

Table 4.1 shows summary statistics for the sample. The first row shows that 34 percent of people report being disabled. Figure 4.1 shows the age and sex adjusted share of people reporting disability by education. There is a clear gradient in disability. The disability rate among people without a high school degree is 47 percent. The share declines to 31 percent for people with a high school degree, and 27 percent for people with some college or a college degree.

2. The vast bulk of people in a nursing home will have been in for less than a decade, so the 2002 survey should be nationally representative by living arrangement.

3. We could alternatively look at the relation between income and disability, but education is more consistent with past research, and perhaps measures permanent income better. 
Table 4.1

Summary statistics

\begin{tabular}{|c|c|c|c|}
\hline Variable & Percent & Variable & Percent \\
\hline Disability rate & 34 & Smoker: current & 15 \\
\hline Education & & Smoker: former & 42 \\
\hline$<$ High school & 28 & Smoker: never & 43 \\
\hline High school & 36 & Drinker: heavy & 3 \\
\hline Some college & 18 & Drinker: light & 43 \\
\hline College grad & 18 & Drinker: never & 32 \\
\hline Childhood health and SES & & Drinker: missing & 22 \\
\hline Needed financial help & 11 & Health conditions & \\
\hline Moved for financial reasons & 19 & High blood pressure & 58 \\
\hline Father unemployed & 23 & Diabetes & 18 \\
\hline SES: Well-off & 5 & Stroke & 8 \\
\hline SES: Average & 60 & Cancer & 18 \\
\hline SES: Poor & 34 & Heart condition & 32 \\
\hline Health: Excellent & 48 & Arthritis & 67 \\
\hline Health: Very good & 27 & Chronic lung disease & 11 \\
\hline Health: Good & 19 & Psychiatric & 14 \\
\hline Health: Fair & 4 & Preventive care & \\
\hline Health: Poor & 2 & Cholesterol test & 77 \\
\hline Height (meters) & 1.7 & Flu shot & 70 \\
\hline Major occupation & & Breast self exam (women) & 59 \\
\hline Professional/managerial & 27 & Mammogram (women) & 71 \\
\hline Sales worker & 8 & Pap smear (women) & 55 \\
\hline Clerical worker & 14 & Prostate exam (men) & 76 \\
\hline Farmer & 5 & Living status & \\
\hline Machine operator & 9 & Socialize daily & 17 \\
\hline Other & 20 & Friends live nearby & 74 \\
\hline Missing/No profession & 17 & Family lives nearby & 32 \\
\hline Behaviors & & Marital status: married & 55 \\
\hline BMI: obese & 19 & Marital status: unmarried, & \\
\hline BMI: overweight & 42 & living with others & 12 \\
\hline BMI: normal weight & 39 & Marital status: unmarried, & \\
\hline BMI: missing & 0 & living alone & 33 \\
\hline
\end{tabular}

Note: Data are from the 2002 HRS. The sample is 9,155 people.

As previously noted, disability in this scale reflects both physical and social functioning. It may be that one is more responsive to education than the other. Figure 4.2 considers this by looking separately at ADL and IADL disability. Both measures of disability decline markedly with education. The decline is uniform with ADL disability, and continuous up to any college experience for IADL disability. The implication is that the trend in figure 4.1 is not a result of a simple process such as a particular physical limitation or impairment in a single aspect of living. We turn to alternative theories of the education gradient in disability in the next section. 


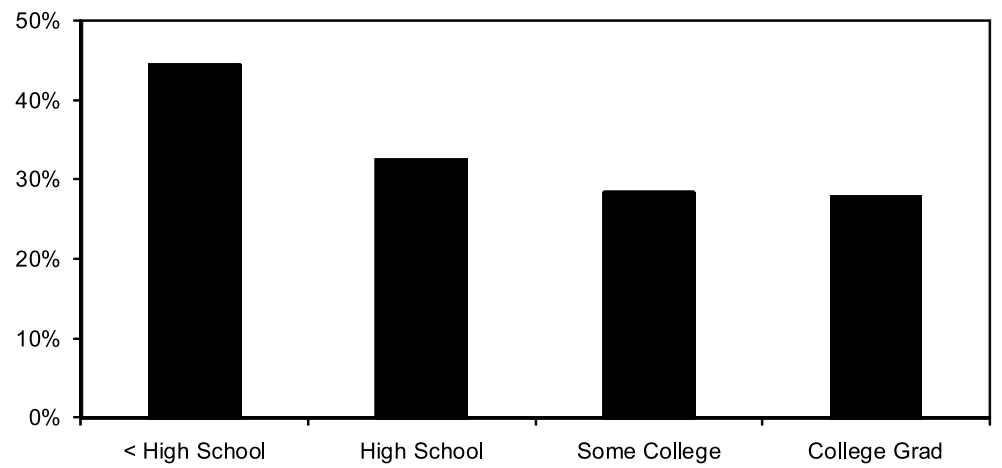

Fig. 4.1 Disability by education

Source: Authors' calculations from the 2002 HRS.

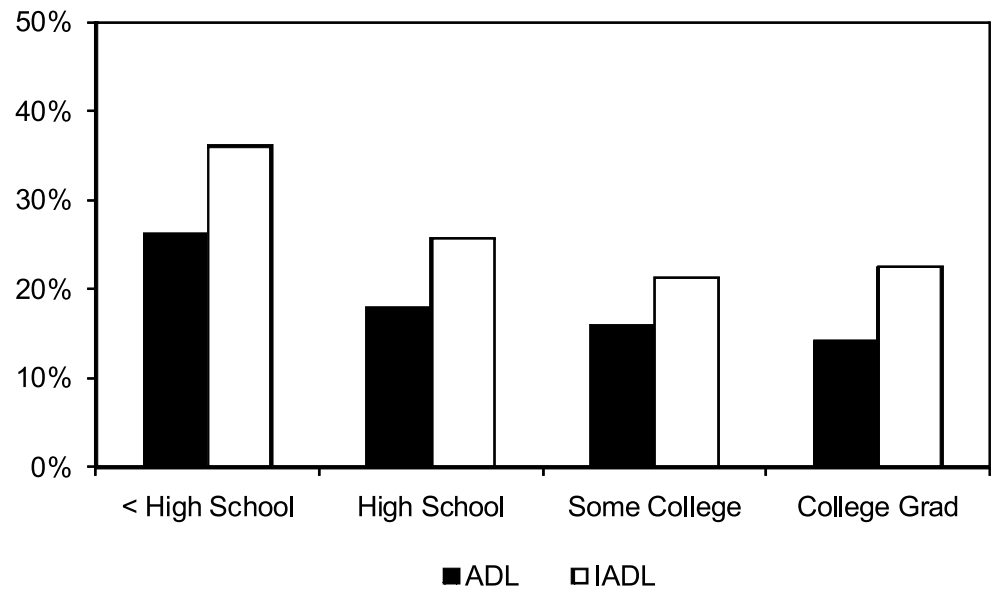

Fig. 4.2 ADL and IADL disability by education

Source: Authors' calculations from the 2002 HRS.

\subsection{Theories of Differential Disability}

There are a number of possible explanations for the marked difference in disability by education. We discuss the theories by their timing over the life course - from earlier in life to later in life. In each case, we also note the data in the HRS that will allow us to test each theory. The schematic in figure 4.3 shows the timing of the different theories.

\subsubsection{Childhood Health and Economic Status}

A substantial literature shows that people who are less healthy as a child continue to be less healthy as an adult. Childhood disease is also associated 


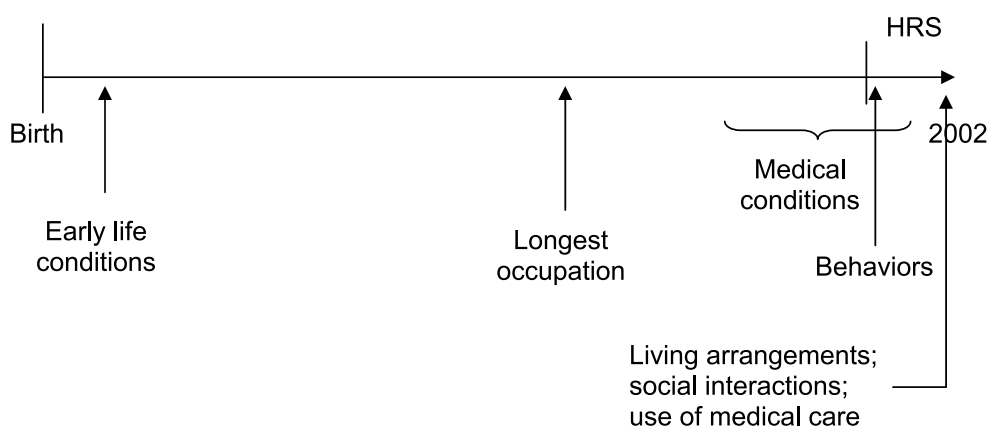

Fig. 4.3 Timing of possible explanations

with receipt of less education. Thus, education and late life health may be related because of their common origin in early life health and socioeconomic differences.

There are several possible reasons this may occur. Barker (1992), for example, argues that babies that do not receive enough nutrition in utero are more likely to develop chronic diseases later in life. In related work, Costa (2002) shows that exposure to infectious disease as a child predicts chronic disease development later in life. Fogel (1994) argues for the general role of nutrition in explaining late life health and longevity, and Case, Lubotsky, and Paxson (2002) show that average income while a child is correlated with health status as a child.

Evidence also shows that health as a child can affect education. Case, Fertig, and Paxson (2005) present evidence that children in worse health receive significantly less education than their peers in better health, and earn less as adults. They are also less healthy as adults.

The HRS has a number of measures of early life health and economic status. On the financial end, people are asked if their family needed financial help as a child, whether they moved for financial reasons, or whether their father was unemployed for a significant time before age sixteen. In addition, people were asked to rate their socioeconomic status as a child: well-off, average, poor, or other. People were also asked to rate their health as a child: excellent, very good, good, fair, or poor. Finally, we include height, which has been shown to reflect nutritional intake as a young child (Fogel 1994). The main limitation of these measures is that they are retrospective and subjective evaluations.

Figure 4.4 shows how these measures of childhood health and economic status are related to subsequent education. Adults with higher education were substantially less likely to have had a father unemployed during their childhood, and were substantially less likely to be poor while growing up. They are also more likely to report that their health status was better in childhood. 


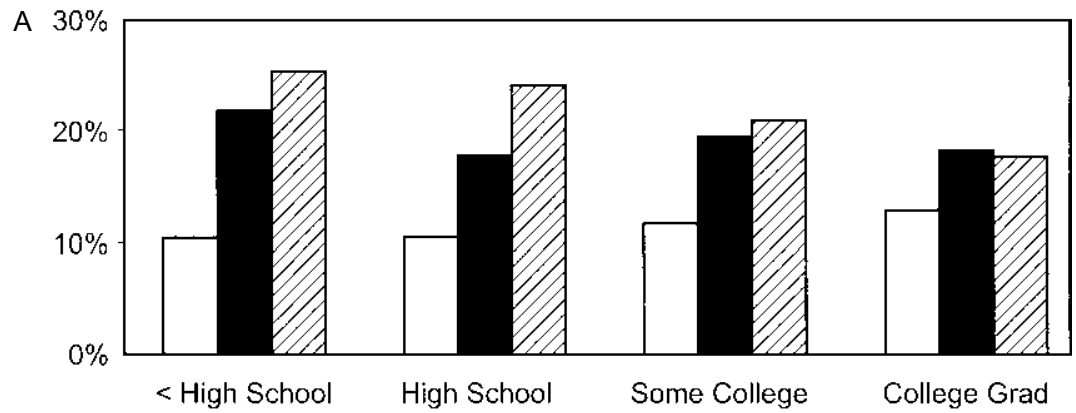

$\square$ Recieved Financial Help $\square$ Moved, Financial Reasons $\square$ Father Unemployed
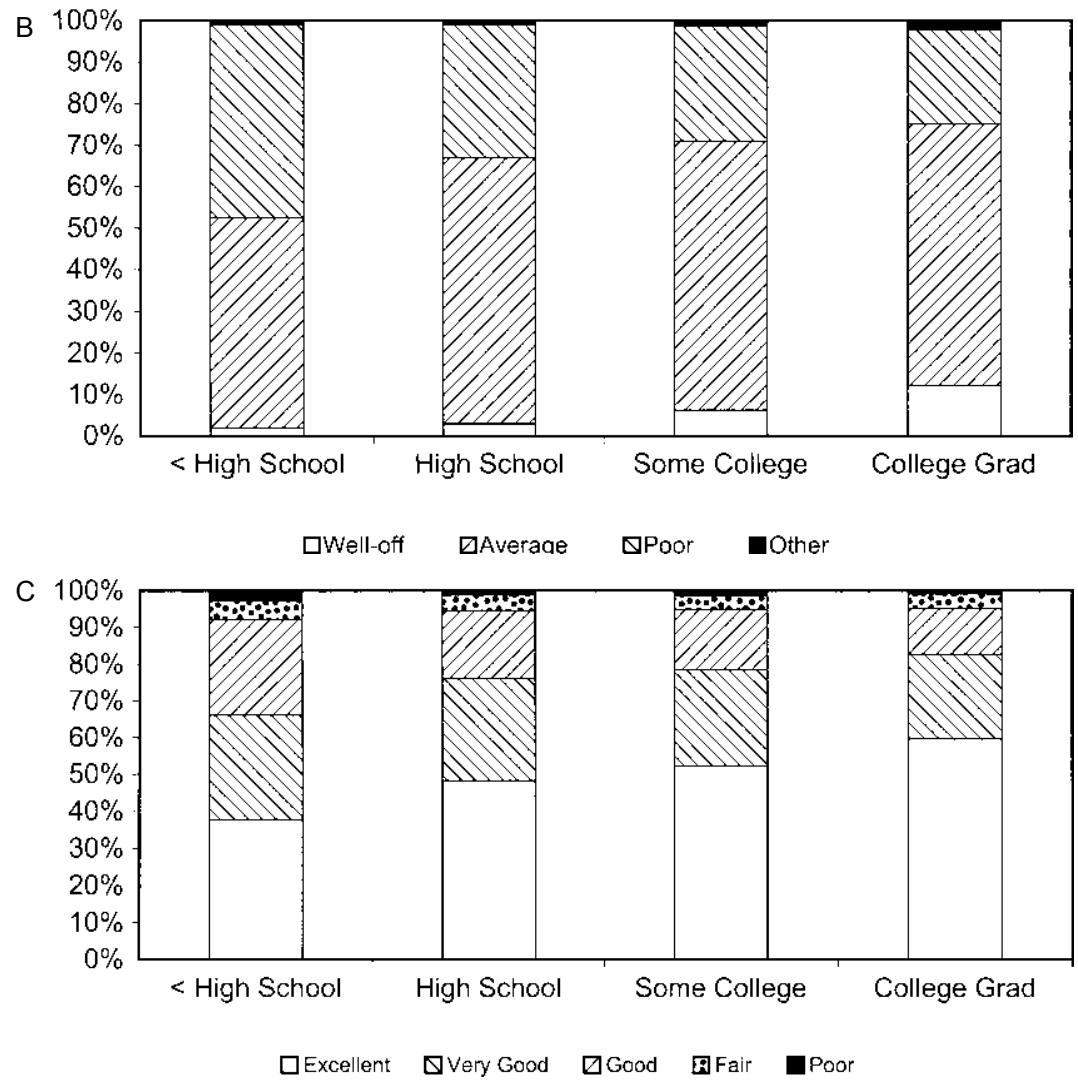

Fig. 4.4 Childhood health and economic status measures: $A$, Financial status; $B$, self-rated SES; $C$, self-rated health

Source: Authors' calculations from the 2002 HRS. 


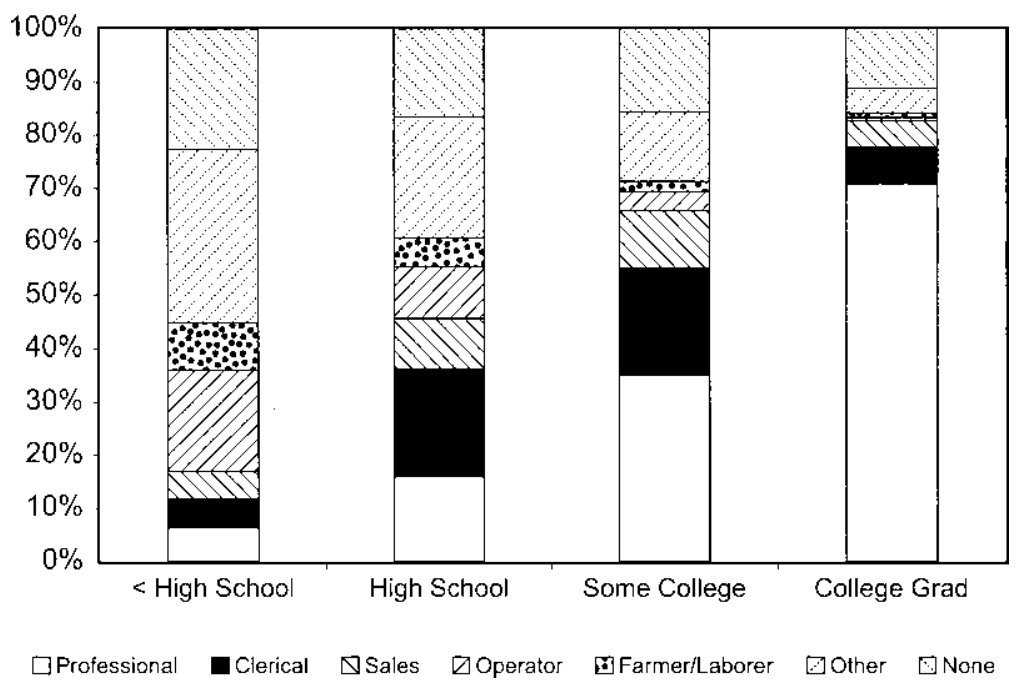

Fig. 4.5 Major occupation

Source: Authors' calculations from the 2002 HRS.

\subsubsection{Occupation}

More educated people work in different jobs than less educated people. They are less likely to engage in manual work and to be exposed to environmental toxins. Differential work experience could thus explain higher rates of late life disability in less educated populations. Indeed, Costa (2002) shows that occupation is associated with late life health among Union Army veterans. Case and Deaton (2005) also find that people in manual occupations have worse and more rapidly declining self-reported health.

The HRS asks about the person's major occupation over their working years. We code these into seven groups: professional/managerial, sales, clerical, machine operator, farmer/laborer, other, and missing or no profession. Figure 4.5 shows that education is strongly related to occupation: college graduates are much more likely to have had professional occupations throughout their lives. High school dropouts are much more likely to report no major occupation or to have worked in manual work.

\subsubsection{Health Behaviors}

Several behaviors are known to affect health status, and could thus be related to disability. The most common such risky behaviors are smoking, obesity, and drinking. Smoking is the most important behavioral cause of mortality, accounting for an estimated 435,000 deaths annually (Mokdad et al. 2004). Obesity is the second leading behavioral cause of mortality, accounting for 100,000 to 400,000 deaths annually, depending on the esti- 
mate. Alcohol is the third most common cause, accounting for nearly 90,000 deaths (Mokdad et al. 2004).

Health behaviors can affect disability directly, or through the diseases they lead to. For example, obese people may have difficulty with mobility, which might be compounded by arthritis or heart disease. We include both medical conditions and health behaviors, with the understanding that the two may be related.

Health behaviors can change over time. Many people will stop smoking after having a heart attack or cancer, for example. Since most behaviors have a lasting effect on health (i.e., former smokers do not have the mortality risk of never smokers), one would ideally like to know about health behaviors over the course of a person's life. The HRS does not ask about long-term weight or drinking. To partly adjust for this, we include health behaviors as of the first year the person was interviewed - in most cases 1992 or 1993. This allows us to have nearly a decade between the behaviors and the measure of disability. While this does not completely eliminate the endogeneity concern about health behaviors, it reduces its importance. ${ }^{4}$

Figure 4.6 shows how age and sex adjusted health behaviors are related to education. The differences are large. The share of people who ever smoked is similar across education groups, but many more highly educated people have quit smoking. The current smoking rate is half as large for college graduates compared to high school dropouts. Obesity is also related to education. Of high school dropouts, 24 percent are obese, compared to 14 percent of college graduates (though the relationship is larger for women). High school dropouts are substantially more likely to never drink, while college graduates are more likely to be light drinkers. Recent evidence suggests that light drinking may be good for health, so this difference does not necessarily indicate poorer health among the better educated. Although heavy drinking is a health risk, there appear to be no differences in self-reported heavy drinking across education groups.

\subsubsection{Medical Conditions}

Many medical conditions lead directly into disability. Conditions such as stroke, arthritis, and heart disease are very disabling. Stroke, for example, often results in mobility limitations and cognitive impairment. If these conditions are less common in the better educated, they could account for education-related differences in disability.

Of course, to the extent that differences in medical conditions are a significant part of the explanation for differential disability by education, one wants to understand why they differ. For example, it may be that the less educated are more likely to suffer from heart disease because of the nature

4. The trade-off is that because we have measures at only one point in time, measurement error may be more of a concern. 


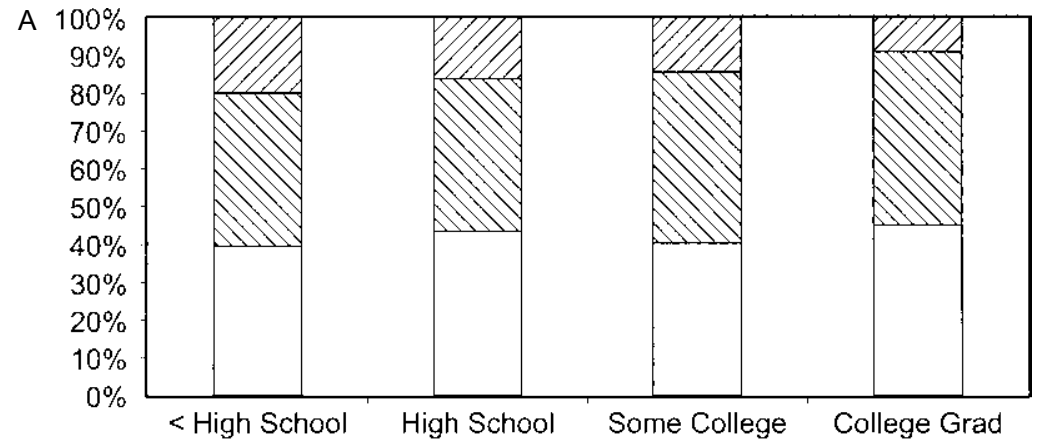

\section{$\square$ Non-smoker $\triangle$ Former Smoker $\square$ Current Smoker}

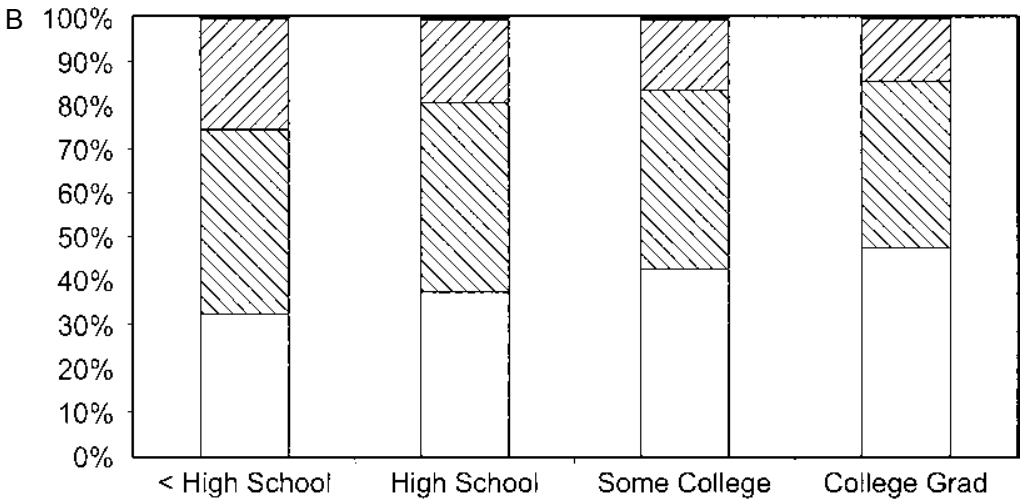

$\square$ Normal $\triangle$ Overweight $\square$ obese $\square$ Missing

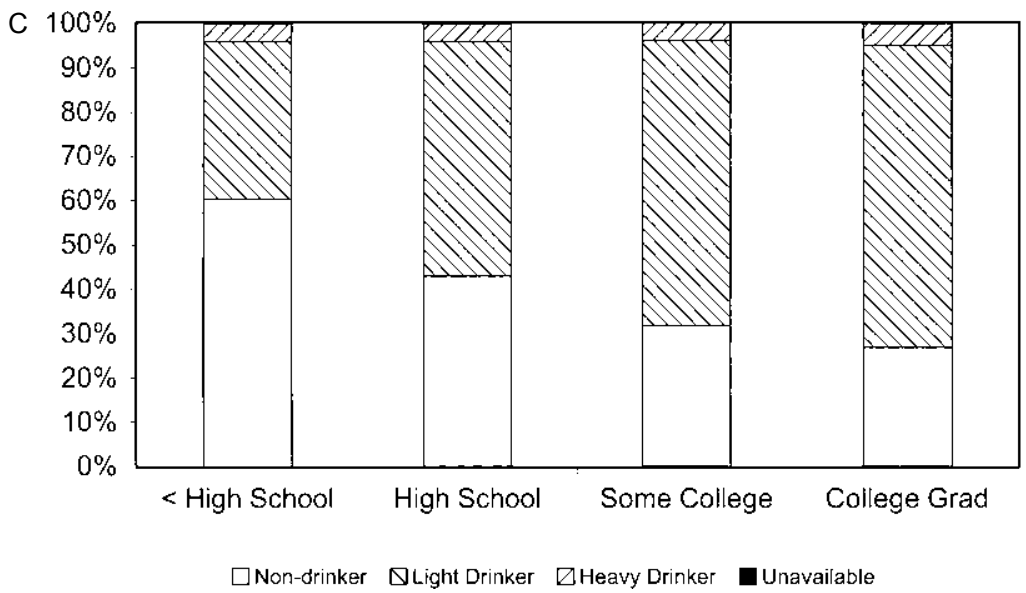

Fig. 4.6 Health behaviors: $A$, Smoking status; $B$, BMI; $C$, Drinking

Source: Authors' calculations from the 2002 HRS. 


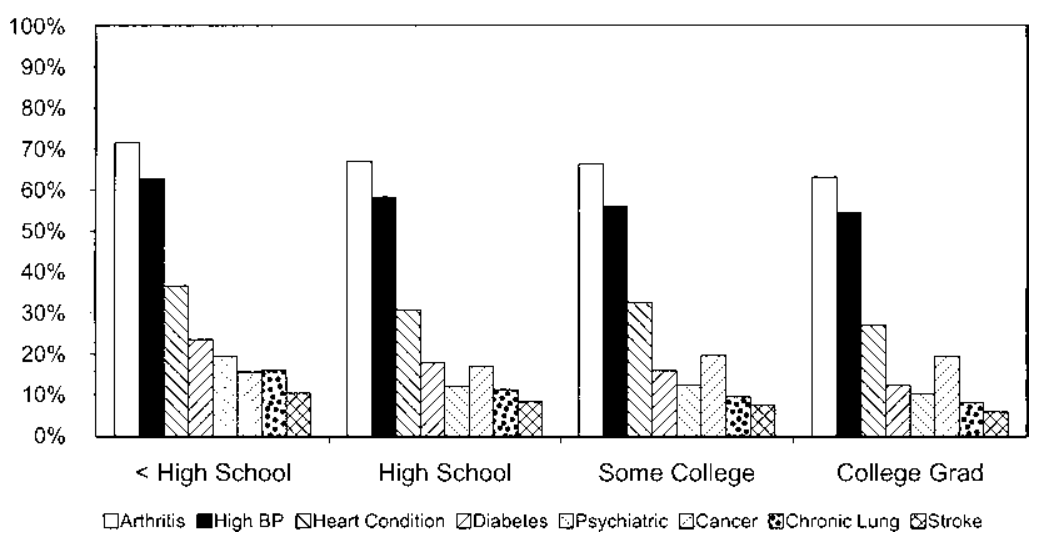

Fig. 4.7 Medical conditions

Source: Authors' calculations from the 2002 HRS.

of their work, or their nutritional intake as a child. It may also be that differences in health behaviors explain disease incidence. In our analysis, we speculate about the reasons for differences in medical conditions, but we do not address the issue definitively.

The HRS asks a number of questions about medical conditions. People are asked if they have ever been told they have hypertension, high cholesterol, diabetes, arthritis, (all chronic diseases) and a heart condition, cancer, stroke, chronic lung disease, or psychiatric problems (acute diseases). We include nine dummies for each of these conditions. The main limitation of these indicators is that they are affected by interactions with the health care system: for example, there may be individuals with hypertension that are not aware of their condition because they have not seen the doctor.

Figure 4.7 shows how disease incidence varies by education. Arthritis is the most common condition in the elderly. Of people without a high school degree, 70 percent report a diagnosis of arthritis, compared to 60 percent of those who are college graduates. Hypertension is nearly as prevalent, and also declines with education. The remaining conditions have lower prevalence, but in virtually every case disease prevalence declines with education. This is somewhat surprising given that the more educated are possibly more likely to be diagnosed conditional on having the disease, and it suggests that the actual differences in disease rates might be even higher. It is thus possible that differential rates of medical conditions explain the education gradient in health behaviors.

\subsubsection{Interaction with the Medical System}

Regular medical interaction may prevent the onset of disability. Medications for hypertension or high cholesterol can reduce their impact on sub- 


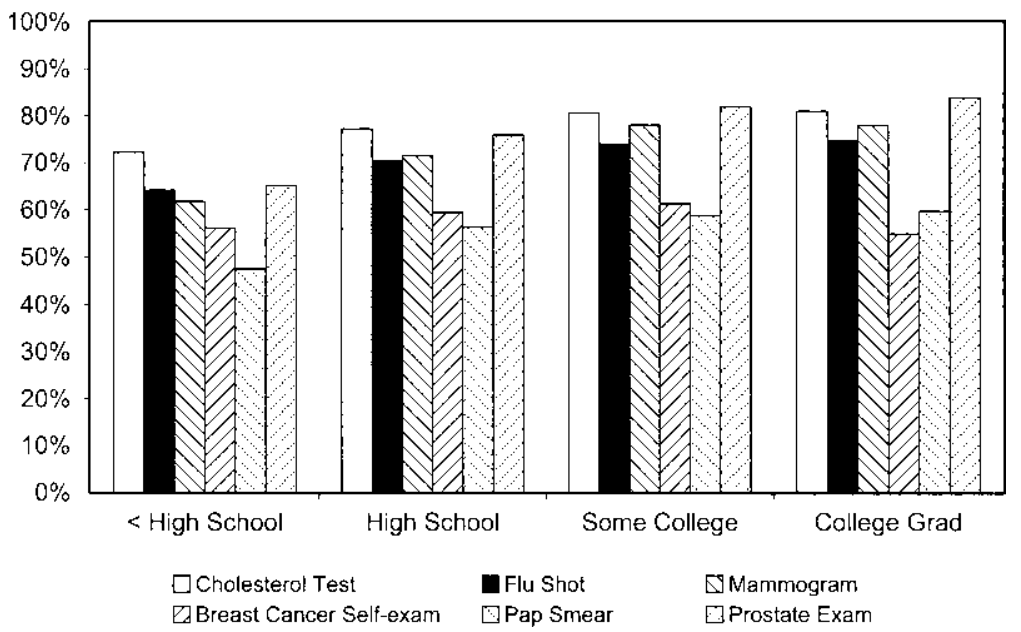

Fig. 4.8 Preventive behavior in last two years

Source: Authors' calculations from the 2002 HRS.

sequent health. Regular screening can catch cancers early and thus extend disease-free survival. Greater use of preventive care may thus explain the lower rate of disability among the better educated.

In addition to its direct effect on health, use of preventive care might be a signal about the importance people attach to health. People who go for regular cancer screenings may also exercise more or otherwise live in environments more suited to maintaining independence. We include preventive care receipt in our regressions, but do not attribute it to either of these two explanations.

The HRS includes a number of measures of prevention. The questions are asked about the time since the previous interview (approximately two years prior). Everyone is asked about cholesterol testing and receipt of a flu shot. Women are asked about breast self-examination, mammography, and receipt of a pap smear. Men are asked about receipt of a prostate-specific antigen (PSA) test.

Figure 4.8 shows how preventive care is related to education. In almost every case, better educated people are more likely to receive preventive medical care. Cholesterol testing, for example, is 10 percent higher for those with a college degree than for high school dropouts. Mammography rates are even more different.

\subsubsection{Living Arrangements}

Disability is not a measure of just physical performance; it reflects what a person needs to do as well. A person with fewer demands will be less disabled than a person with more demands, health status held constant. An important factor influencing need is the person's living status. A married per- 
son will (often) have help from their spouse lifting grocery bags, managing money, and cleaning house. Thus, at the same level of physical performance, a married person is less likely to be disabled than a person living alone. Similarly, people who socialize regularly or have many friends may have implicit help managing usual activities. All of this could lead to lower disability.

While living arrangements will affect disability, they might be influenced by disability as well. People who are disabled will need help from others; they might choose to live near their children. On the other hand, people in poor health may find remarriage difficult after a spouse dies, and keeping up with friends may be too taxing. Disability may thus cause a person to remain alone. Sorting out the causal relation between living arrangements and disability is difficult without a good instrument for living arrangements. We do not have such an instrument. As a result, we include living arrangements only as the last variable, and without a strong causal interpretation.

Figure 4.9 shows the education gradient in living arrangements. Better
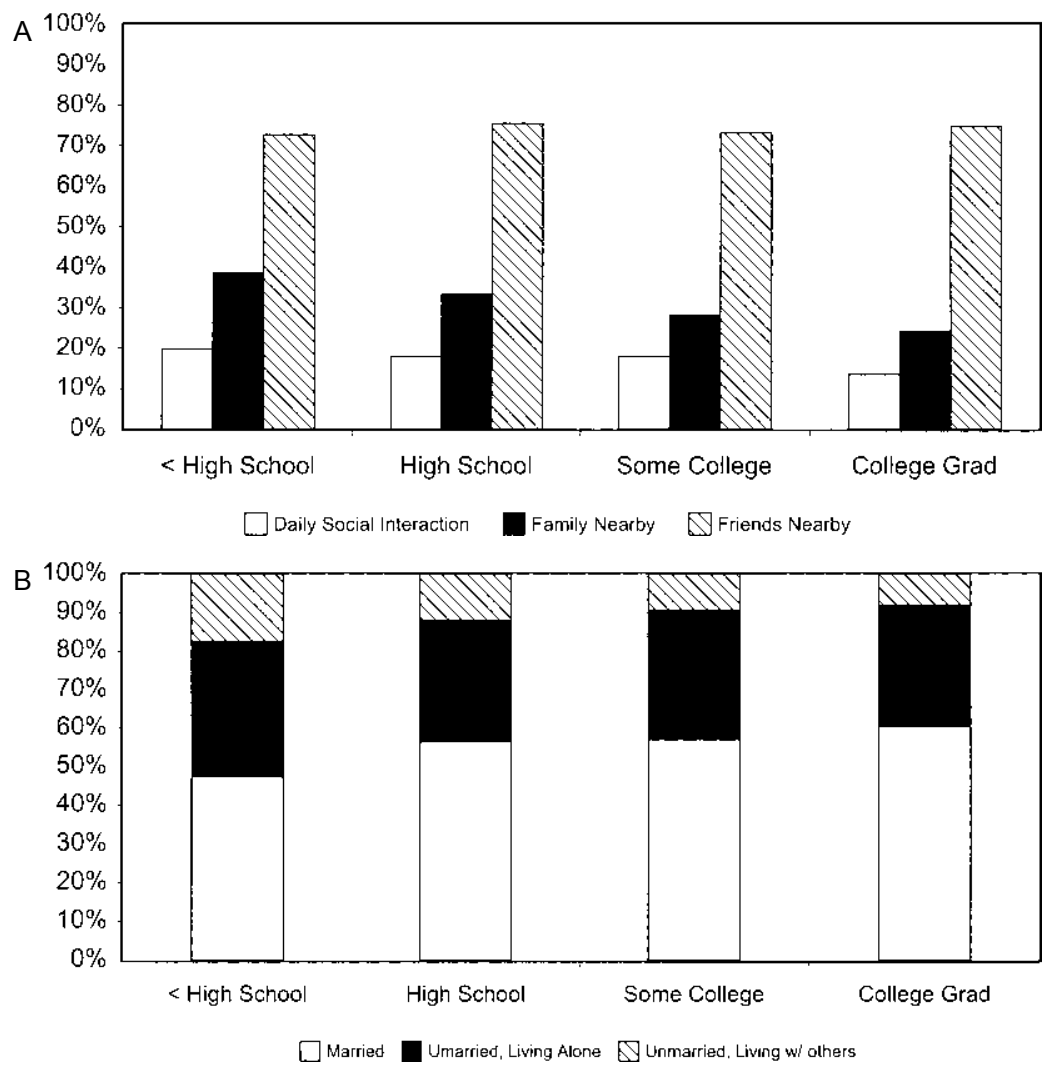

Fig. 4.9 Social interactions (yes/no) and living arrangements: $A$, Social interactions; $B$, Living arrangements

Source: Authors' calculations from the 2002 HRS. 
educated people live farther away from family, but are more likely to be married. The implication for disability is not entirely clear.

\subsection{Empirical Analysis of Disability}

Having discussed our different variables possibly mediating the link between education and disability, in this section we examine them empirically. Our methodology is relatively simple: we start with a basic regression of disability on five year age by sex dummy variables and education:

$$
\text { Disability }_{i}=\beta_{0}+\frac{\text { age }}{\operatorname{sex}_{i}}, \text { region }_{i}+\beta_{1} * \text { Education }_{i}+\varepsilon_{i} .
$$

For expositional ease, equation (1) shows education entered linearly, though our actual empirical models divide education into four groups. From our earlier means, we know that the coefficient $\beta_{1}$ will be negative: better educated people are less likely to be disabled.

We then augment this equation by including the other mediating variables, in sequence:

$$
\text { Disability }_{i}=\alpha_{0}+\frac{\text { age }}{\operatorname{sex}_{i}}, \text { region }_{i}+\alpha_{1}{ }^{*} \text { Education }_{i}+\mathbf{X}_{i} \alpha+\varepsilon_{i} .
$$

To the extent that these variables explain the education gradient in disability, the coefficient $\alpha_{1}$ will be smaller than the corresponding coefficient $\beta_{1}$. We measure the importance of each variable to the education gradient by calculating $\left(1-\alpha_{1}\right) / \beta_{1}$, the decline in the education coefficient relative to the coefficient without any controls.

Because disability is a dichotomous variable, we estimate equations (1) and (2) as probit models. For interpretation, we report the implied change in the probability of being disabled.

Table 4.2 shows our regression results. The first column includes education and the age/sex and region controls, but no other variables. The coefficients match those in the figures. Relative to people with just a high school degree, high school dropouts have a 12 percent higher risk of being disabled. College graduates, in contrast, have a 5 percent lower risk of being disabled.

The second column includes the childhood social and economic measures. Including these measures has relatively little effect on the education gradient in disability. The coefficient on high school dropouts declines by only 7 percent, and the coefficient on college graduates falls by only 8 percent.

The most important variables to include are the longest occupation, health behaviors, and medical conditions. In each case, including these variables has a significant impact on the education gradient in disability. Including major occupation, for example, reduces the coefficient on college graduates by 32 percent. Adding health behaviors accounts for an additional 


\begin{tabular}{|c|c|c|c|c|c|c|c|}
\hline Independent variable & (1) & (2) & (3) & (4) & (5) & (6) & (7) \\
\hline \multicolumn{8}{|l|}{ Education $^{\mathrm{a}}$} \\
\hline$<$ High school & $\begin{array}{c}0.122 \\
(0.014)\end{array}$ & $\begin{array}{c}0.114 \\
(0.014)\end{array}$ & $\begin{array}{c}0.095 \\
(0.015)\end{array}$ & $\begin{array}{c}0.081 \\
(0.016)\end{array}$ & $\begin{array}{c}0.065 \\
(0.015)\end{array}$ & $\begin{array}{c}0.059 \\
(0.015)\end{array}$ & $\begin{array}{r}0.056 \\
(0.014)\end{array}$ \\
\hline Some college & $\begin{array}{l}-0.042 \\
(0.017)\end{array}$ & $\begin{array}{l}-0.040 \\
(0.017)\end{array}$ & $\begin{array}{l}-0.030 \\
(0.018)\end{array}$ & $\begin{array}{l}-0.021 \\
(0.018)\end{array}$ & $\begin{array}{l}-0.024 \\
(0.018)\end{array}$ & $\begin{array}{l}-0.020 \\
(0.018)\end{array}$ & $\begin{array}{l}-0.018 \\
(0.018)\end{array}$ \\
\hline College grad & $\begin{array}{l}-0.052 \\
(0.017)\end{array}$ & $\begin{array}{l}-0.048 \\
(0.017)\end{array}$ & $\begin{array}{l}-0.032 \\
(0.019)\end{array}$ & $\begin{array}{l}-0.012 \\
(0.020)\end{array}$ & $\begin{array}{l}-0.001 \\
(0.022)\end{array}$ & $\begin{array}{c}0.000 \\
(0.022)\end{array}$ & $\begin{array}{r}0.004 \\
(0.021)\end{array}$ \\
\hline \multicolumn{8}{|l|}{ Share of no control effect } \\
\hline$<$ High school & - & $93 \%$ & $78 \%$ & $66 \%$ & $53 \%$ & $48 \%$ & $46 \%$ \\
\hline Some college & - & $96 \%$ & $73 \%$ & $49 \%$ & $56 \%$ & $48 \%$ & $43 \%$ \\
\hline College grad & - & $92 \%$ & $60 \%$ & $23 \%$ & $2 \%$ & $-1 \%$ & $-7 \%$ \\
\hline \multicolumn{8}{|l|}{ Childhood health and SES ${ }^{b}$} \\
\hline Needed financial help & - & $\begin{array}{c}0.021 \\
(0.017)\end{array}$ & $\begin{array}{c}0.021 \\
(0.017)\end{array}$ & $\begin{array}{c}0.023 \\
(0.017)\end{array}$ & $\begin{array}{c}0.017 \\
(0.017)\end{array}$ & $\begin{array}{c}0.017 \\
(0.018)\end{array}$ & $\begin{array}{c}0.015 \\
(0.018)\end{array}$ \\
\hline $\begin{array}{l}\text { Moved for financial } \\
\text { reasons }\end{array}$ & - & $\begin{array}{c}0.011 \\
(0.014)\end{array}$ & $\begin{array}{c}0.011 \\
(0.014)\end{array}$ & $\begin{array}{c}0.012 \\
(0.014)\end{array}$ & $\begin{array}{c}0.007 \\
(0.015)\end{array}$ & $\begin{array}{c}0.007 \\
(0.015)\end{array}$ & $\begin{array}{c}0.008 \\
(0.015)\end{array}$ \\
\hline Father unemployed & - & $\begin{array}{l}-0.017 \\
(0.014)\end{array}$ & $\begin{array}{l}-0.017 \\
(0.014)\end{array}$ & $\begin{array}{l}-0.016 \\
(0.014)\end{array}$ & $\begin{array}{l}-0.018 \\
(0.014)\end{array}$ & $\begin{array}{l}-0.017 \\
(0.014)\end{array}$ & $\begin{array}{l}-0.017 \\
(0.014)\end{array}$ \\
\hline SES: Well-off & - & $\begin{array}{l}-0.030 \\
(0.030)\end{array}$ & $\begin{array}{l}-0.032 \\
(0.030)\end{array}$ & $\begin{array}{l}-0.028 \\
(0.029)\end{array}$ & $\begin{array}{l}-0.031 \\
(0.028)\end{array}$ & $\begin{array}{l}-0.029 \\
(0.028)\end{array}$ & $\begin{array}{l}-0.031 \\
(0.028)\end{array}$ \\
\hline SES: Poor & - & $\begin{array}{l}-0.005 \\
(0.014)\end{array}$ & $\begin{array}{l}-0.006 \\
(0.014)\end{array}$ & $\begin{array}{c}0.000 \\
(0.013)\end{array}$ & $\begin{array}{c}0.005 \\
(0.014)\end{array}$ & $\begin{array}{c}0.007 \\
(0.014)\end{array}$ & $\begin{array}{c}0.008 \\
(0.014)\end{array}$ \\
\hline Health: Excellent & - & $\begin{array}{l}-0.057 \\
(0.016)\end{array}$ & $\begin{array}{l}-0.055 \\
(0.016)\end{array}$ & $\begin{array}{l}-0.059 \\
(0.016)\end{array}$ & $\begin{array}{l}-0.044 \\
(0.016)\end{array}$ & $\begin{array}{l}-0.044 \\
(0.017)\end{array}$ & $\begin{array}{l}-0.042 \\
(0.017)\end{array}$ \\
\hline Health: Very good & - & $\begin{array}{l}-0.059 \\
(0.020)\end{array}$ & $\begin{array}{l}-0.058 \\
(0.020)\end{array}$ & $\begin{array}{l}-0.056 \\
(0.020)\end{array}$ & $\begin{array}{l}-0.051 \\
(0.019)\end{array}$ & $\begin{array}{l}-0.050 \\
(0.019)\end{array}$ & $\begin{array}{l}-0.049 \\
(0.020)\end{array}$ \\
\hline Health: Fair & - & $\begin{array}{c}0.062 \\
(0.031)\end{array}$ & $\begin{array}{c}0.060 \\
(0.032)\end{array}$ & $\begin{array}{c}0.057 \\
(0.032)\end{array}$ & $\begin{array}{c}0.040 \\
(0.031)\end{array}$ & $\begin{array}{c}0.040 \\
(0.031)\end{array}$ & $\begin{array}{c}0.046 \\
(0.032)\end{array}$ \\
\hline Health: Poor & - & $\begin{array}{c}0.067 \\
(0.039)\end{array}$ & $\begin{array}{c}0.075 \\
(0.038)\end{array}$ & $\begin{array}{c}0.071 \\
(0.035)\end{array}$ & $\begin{array}{c}0.025 \\
(0.035)\end{array}$ & $\begin{array}{c}0.020 \\
(0.034)\end{array}$ & $\begin{array}{r}0.030 \\
(0.035)\end{array}$ \\
\hline Height (meters) & - & $\begin{array}{c}0.025 \\
(0.076)\end{array}$ & $\begin{array}{c}0.034 \\
(0.076)\end{array}$ & $\begin{array}{c}0.083 \\
(0.074)\end{array}$ & $\begin{array}{c}0.029 \\
(0.075)\end{array}$ & $\begin{array}{c}0.036 \\
(0.076)\end{array}$ & $\begin{array}{c}0.046 \\
(0.077)\end{array}$ \\
\hline Missing height & - & $\begin{array}{c}0.207 \\
(0.310)\end{array}$ & $\begin{array}{c}0.209 \\
(0.310)\end{array}$ & $\begin{array}{c}0.296 \\
(0.320)\end{array}$ & $\begin{array}{c}0.250 \\
(0.330)\end{array}$ & $\begin{array}{c}0.286 \\
(0.330)\end{array}$ & $\begin{array}{c}0.288 \\
(0.330)\end{array}$ \\
\hline \multicolumn{8}{|l|}{ Major occupation $^{\mathrm{c}}$} \\
\hline Professional/managerial & - & - & $\begin{array}{c}-0.051 \\
(0.031)\end{array}$ & $\begin{array}{c}-0.049 \\
(0.031)\end{array}$ & $\begin{array}{c}-0.054 \\
(0.034)\end{array}$ & $\begin{array}{l}-0.050 \\
(0.034)\end{array}$ & $\begin{array}{c}-0.044 \\
(0.034)\end{array}$ \\
\hline Sales worker & - & - & $\begin{array}{l}-0.058 \\
(0.035)\end{array}$ & $\begin{array}{l}-0.056 \\
(0.035)\end{array}$ & $\begin{array}{l}-0.058 \\
(0.036)\end{array}$ & $\begin{array}{l}-0.056 \\
(0.037)\end{array}$ & $\begin{array}{l}-0.047 \\
(0.037)\end{array}$ \\
\hline Clerical worker & - & - & $\begin{array}{c}-0.068 \\
(0.038)\end{array}$ & $\begin{array}{c}-0.060 \\
(0.039)\end{array}$ & $\begin{array}{c}-0.065 \\
(0.041)\end{array}$ & $\begin{array}{l}-0.062 \\
(0.042)\end{array}$ & $\begin{array}{l}-0.055 \\
(0.042)\end{array}$ \\
\hline Machine operator & - & - & $\begin{array}{c}-0.001 \\
(0.041)\end{array}$ & $\begin{array}{c}-0.008 \\
(0.041)\end{array}$ & $\begin{array}{c}-0.010 \\
(0.043)\end{array}$ & $\begin{array}{c}-0.008 \\
(0.044)\end{array}$ & $\begin{array}{c}-0.002 \\
(0.043)\end{array}$ \\
\hline Other & - & - & $\begin{array}{c}-0.007 \\
(0.031)\end{array}$ & $\begin{array}{l}-0.015 \\
(0.030)\end{array}$ & $\begin{array}{l}-0.019 \\
(0.033)\end{array}$ & $\begin{array}{l}-0.015 \\
(0.034)\end{array}$ & $\begin{array}{c}-0.009 \\
(0.034)\end{array}$ \\
\hline Missing/No profession & - & - & $\begin{array}{c}0.027 \\
(0.034)\end{array}$ & $\begin{array}{c}0.027 \\
(0.034)\end{array}$ & $\begin{array}{c}0.018 \\
(0.037)\end{array}$ & $\begin{array}{c}0.017 \\
(0.036)\end{array}$ & $\begin{array}{c}0.023 \\
(0.037)\end{array}$ \\
\hline
\end{tabular}




\begin{tabular}{|c|c|c|c|c|c|c|c|}
\hline Independent variable & (1) & (2) & (3) & (4) & (5) & (6) & (7) \\
\hline \multicolumn{8}{|l|}{ Behavior $^{d}$} \\
\hline BMI: obese & - & - & - & $\begin{array}{c}0.138 \\
(0.015)\end{array}$ & $\begin{array}{c}0.105 \\
(0.015)\end{array}$ & $\begin{array}{c}0.101 \\
(0.015)\end{array}$ & $\begin{array}{c}0.098 \\
(0.015)\end{array}$ \\
\hline BMI: overweight & - & - & - & $\begin{array}{c}0.033 \\
(0.010)\end{array}$ & $\begin{array}{c}0.023 \\
(0.010)\end{array}$ & $\begin{array}{c}0.021 \\
(0.010)\end{array}$ & $\begin{array}{c}0.022 \\
(0.010)\end{array}$ \\
\hline BMI: missing & - & - & - & $\begin{array}{c}0.047 \\
(0.100)\end{array}$ & $\begin{array}{c}0.022 \\
(0.097)\end{array}$ & $\begin{array}{c}0.020 \\
(0.096)\end{array}$ & $\begin{array}{c}0.024 \\
(0.098)\end{array}$ \\
\hline Smoker: current & - & - & - & $\begin{array}{c}0.104 \\
(0.020)\end{array}$ & $\begin{array}{c}0.071 \\
(0.021)\end{array}$ & $\begin{array}{c}0.062 \\
(0.021)\end{array}$ & $\begin{array}{r}0.056 \\
(0.022)\end{array}$ \\
\hline Smoker: former & - & - & - & $\begin{array}{c}0.020 \\
(0.013)\end{array}$ & $\begin{array}{l}-0.003 \\
(0.014)\end{array}$ & $\begin{array}{l}-0.003 \\
(0.014)\end{array}$ & $\begin{array}{c}-0.004 \\
(0.014)\end{array}$ \\
\hline Drinker: heavy & - & - & - & $\begin{array}{l}-0.017 \\
(0.024)\end{array}$ & $\begin{array}{c}0.009 \\
(0.025)\end{array}$ & $\begin{array}{c}0.005 \\
(0.025)\end{array}$ & $\begin{array}{c}0.006 \\
(0.025)\end{array}$ \\
\hline Drinker: light & - & - & - & $\begin{array}{l}-0.077 \\
(0.014)\end{array}$ & $\begin{array}{l}-0.066 \\
(0.014)\end{array}$ & $\begin{array}{c}-0.063 \\
(0.015)\end{array}$ & $\begin{array}{r}-0.060 \\
(0.015)\end{array}$ \\
\hline Drinker: missing & - & - & - & $\begin{array}{c}-0.012 \\
(0.016)\end{array}$ & $\begin{array}{c}0.003 \\
(0.016)\end{array}$ & $\begin{array}{c}0.006 \\
(0.016)\end{array}$ & $\begin{array}{c}0.007 \\
(0.016)\end{array}$ \\
\hline \multicolumn{8}{|l|}{ Health conditions } \\
\hline High blood pressure & - & - & - & - & $\begin{array}{c}-0.027 \\
(0.011)\end{array}$ & $\begin{array}{c}-0.021 \\
(0.011)\end{array}$ & $\begin{array}{c}-0.023 \\
(0.011)\end{array}$ \\
\hline Diabetes & - & - & - & - & $\begin{array}{c}0.052 \\
(0.020)\end{array}$ & $\begin{array}{c}0.054 \\
(0.020)\end{array}$ & $\begin{array}{r}0.050 \\
(0.020)\end{array}$ \\
\hline Stroke & - & - & - & - & $\begin{array}{c}0.199 \\
(0.022)\end{array}$ & $\begin{array}{c}0.196 \\
(0.021)\end{array}$ & $\begin{array}{c}0.189 \\
(0.021)\end{array}$ \\
\hline Cancer & - & - & - & - & $\begin{array}{c}0.022 \\
(0.013)\end{array}$ & $\begin{array}{c}0.027 \\
(0.013)\end{array}$ & $\begin{array}{c}0.028 \\
(0.013)\end{array}$ \\
\hline Heart condition & - & - & - & - & $\begin{array}{c}0.072 \\
(0.014)\end{array}$ & $\begin{array}{c}0.073 \\
(0.014)\end{array}$ & $\begin{array}{r}0.073 \\
(0.014)\end{array}$ \\
\hline Arthritis & - & - & - & - & $\begin{array}{c}0.067 \\
(0.012)\end{array}$ & $\begin{array}{c}0.072 \\
(0.013)\end{array}$ & $\begin{array}{r}0.073 \\
(0.013)\end{array}$ \\
\hline Chronic lung disease & - & - & - & - & $\begin{array}{c}0.067 \\
(0.018)\end{array}$ & $\begin{array}{c}0.070 \\
(0.017)\end{array}$ & $\begin{array}{c}0.067 \\
(0.017)\end{array}$ \\
\hline Psychiatric & - & - & - & - & $\begin{array}{c}0.162 \\
(0.018)\end{array}$ & $\begin{array}{c}0.161 \\
(0.018)\end{array}$ & $\begin{array}{c}0.158 \\
(0.018)\end{array}$ \\
\hline \multicolumn{8}{|l|}{ Preventive care } \\
\hline Cholesterol test & - & - & - & - & - & $\begin{array}{l}-0.015 \\
(0.014)\end{array}$ & $\begin{array}{l}-0.011 \\
(0.014)\end{array}$ \\
\hline Flu shot & - & - & - & - & - & $\begin{array}{c}0.007 \\
(0.013)\end{array}$ & $\begin{array}{c}0.009 \\
(0.013)\end{array}$ \\
\hline Breast self exam (women) & - & - & - & - & - & $\begin{array}{c}-0.049 \\
(0.015)\end{array}$ & $\begin{array}{c}-0.047 \\
(0.015)\end{array}$ \\
\hline Mammogram (women) & - & - & - & - & - & $\begin{array}{c}-0.039 \\
(0.022)\end{array}$ & $\begin{array}{c}-0.033 \\
(0.023)\end{array}$ \\
\hline Pap smear (women) & - & - & - & - & - & $\begin{array}{c}-0.044 \\
(0.016)\end{array}$ & $\begin{array}{l}-0.045 \\
(0.017)\end{array}$ \\
\hline Prostate exam (men) & - & - & - & - & - & $\begin{array}{c}-0.054 \\
(0.019)\end{array}$ & $\begin{array}{c}-0.054 \\
(0.018)\end{array}$ \\
\hline
\end{tabular}


Table 4.2

(continued)

\begin{tabular}{|c|c|c|c|c|c|c|c|}
\hline Independent variable & (1) & (2) & (3) & (4) & (5) & (6) & (7) \\
\hline \multicolumn{8}{|l|}{ Living status ${ }^{\mathrm{e}}$} \\
\hline Socialize daily & - & - & - & - & - & - & $\begin{array}{l}-0.018 \\
(0.015)\end{array}$ \\
\hline Friends live nearby & - & - & - & - & - & - & $\begin{array}{l}-0.040 \\
(0.015)\end{array}$ \\
\hline Family lives nearby & - & - & - & - & - & - & $\begin{array}{r}0.033 \\
(0.013)\end{array}$ \\
\hline $\begin{array}{l}\text { Marital status: unmarried, } \\
\text { living with others }\end{array}$ & - & - & - & - & - & - & $\begin{array}{r}0.084 \\
(0.017)\end{array}$ \\
\hline $\begin{array}{l}\text { Marital status: unmarried, } \\
\text { living alone }\end{array}$ & - & - & - & - & - & - & $\begin{array}{l}-0.020 \\
(0.015)\end{array}$ \\
\hline Observations & 9,155 & 9,155 & 9,155 & 9,155 & 9,155 & 9,155 & 9,155 \\
\hline
\end{tabular}

Notes: Data are from the 2002 HRS. All regressions control for give year age-sex dummy variables, and dummy variables for region of residence. Standard errors are in parentheses. Dashed cells indicate not included in regression.

a Omitted education is high school graduate.

${ }^{\mathrm{b}}$ Childhood SES is relative to average and health is relative to good.

cProfessions are relative to farmers and laborers.

${ }^{\mathrm{d}} \mathrm{BMI}$ is relative to normal weight, smoker is relative to never smoker, and drinker is relative to nondrinker.

${ }^{\mathrm{e}}$ Living status is relative to married.

37 percent, and medical conditions is another 21 percent. In the fifth column of the table, the residual difference in disability for people who are college graduates is positive, although not statistically significant. Adding either preventive care or living arrangements measures does not significantly affect the results, once occupation, medical conditions, and health behaviors are accounted for.

Occupation, health behaviors, and medical conditions reduce the impact of low education as well, although the impact is somewhat smaller. Compared to the 7 percent reduction from including childhood socioeconomic status (SES) and health factors, the impact of occupation, health behaviors, and medical conditions is each 12 to 15 percent. Including living status and preventive care is associated with modest further reductions in the education effect, especially for high school dropouts. The combined impact is 7 percent. In total, however, only 54 percent of the higher disability rate for high school dropouts is a result of the factors we identify.

The impact of major occupation on disability is largely along white-collar and blue-collar lines. Farmers/laborers (the omitted category) and machine operators have the highest disability rates. Professional/managerial, clerical, and sales workers all have disability rates that are 5 to 7 percent lower. In 
this sense, our results are different from those of Marmot and colleagues, who find a graded difference in mortality rates throughout the occupational distribution.

Obesity and current smoking are the health behaviors most associated with disability. In column (4), obese people are 14 percent more likely to be disabled than normal weight people, all else constant. Smokers are 10 percent more likely to be disabled. Heavy drinking is not associated with a statistically significantly higher disability rate; indeed, the coefficient is negative, but not significant. Further results (not shown) indicate that smoking and obesity contribute approximately equally to the education gradient in disability; both are key behaviors in understanding the education gradient in health.

Stroke is the most disabling medical condition. People who suffer a stroke are 20 percent more likely to be disabled than similar people without a stroke. Heart conditions, arthritis, and chronic lung disease each add 7 percent to disability rates. These conditions are to a great extent a product of smoking and obesity. Thus, we suspect that a high percentage of the impact of medical conditions on disability is a reflection of underlying health behaviors and the bad events that flow from them. The exception to this is psychiatric problems, which are very disabling (16 percent), but much less a product of smoking or weight management.

We included the explanatory variables with a particular ordering-from early life influences to later life influences. This generally makes temporal sense, but one also wonders whether the results differ if the later life variables are included without the early life variables. In general, the results are very similar. Consider, for example, the difference in disability between high school graduates and college graduates. Relative to the regression with age/sex and region controls only, the impact of including just preventive care receipt is a reduction of 2 percent and the impact of including living conditions is 13 percent. In contrast, including just occupation reduces the college/high school gap by 29 percent, including just health behaviors reduces the gap by 44 percent, and including just health conditions reduces the gap by 35 percent. Thus, our results are largely unaffected by the temporal ordering that we present.

\subsection{Implications}

Our results suggest three factors as being most important in explaining the education gradient in disability. The first is a lifetime of blue-collar work. People are, in perhaps a literal sense, broken down by hard work. Occupation explains 15 to 30 percent of the education differential in disability.

An equally large factor is health behaviors. Better educated people are less likely to smoke and are less likely to be obese. In the case of smoking, the difference is not so much smoking initiation (a decision made early 
in life), but smoking cessation. The share of people who ever smoked is roughly similar by education; quitting behavior, in contrast, is very different. Different health behaviors, and their disease consequences, explain another third of the education gradient in disability.

The final important factor is medical conditions that are not attributable to these risk behaviors. Psychiatric problems have a major effect on disability, but the pathway is almost certainly not through smoking and weight management. Similarly, receipt of preventive care mildly affects disability, and this too would be through a different channel. The reason for the education gradient in mental health is not entirely clear.

The major issue raised by our results is why better educated people behave better. What explains the fact that better educated people can quit smoking more or not succumb to the temptations of ready food? We do not have the answers to these questions, but they are high priorities for future research.

\section{References}

Barker, D. J. P. 1992. Fetal and infant origins of adult disease. London: BMJ Books.

Case, A. C., and A. Deaton. 2005. Broken down by age and sex: How our health declines. In Analyses in the economics of aging, ed. D. Wise, 185-205. Chicago: University of Chicago Press.

Case, A. C., A. Fertig, and C. Paxson. 2005. The lasting impact of childhood health and circumstance. Journal of Health Economics 24 (2): 365-89.

Case, A. C., D. Lubotsky, and C. Paxson. 2002. Economic status and health in childhood: The origins of the gradient. American Economic Review 92 (5): 1308-34.

Chernew, M., D. Goldman, F. Pan, and B. Shang. 2005. Disability and health care expenditures among Medicare beneficiaries. Health Affairs, September 26 (Web Exclusive).

Costa, D. 2002. Changing chronic disease rates and long-term declines in functional limitation among older men. Demography 39 (1): 119-38.

Cutler, D. M. 2001. Declining disability among the elderly. Health Affairs 20 (6): $11-27$.

Cutler, D. M., and A. Lleras-Muney. 2007a. Education and health: Evaluating theories and evidence. In The effects of social and economic policy on health, ed. J. House, R. Schoeni, G. Kaplan, and H. Pollack, 29-60. New York: Russell Sage Foundation. script.

Fogel, R. W. 1994. Economic growth, population theory, and physiology: The bearing of long-term processes on the making of economic policy. American Economic Review 84 (3): 369-95.

Manton, K. G. 1988. A longitudinal study of functional change and mortality in the United States. Journal of Gerontology 43 (5): S153-S161.

Mokdad, A. H., J. S. Marks, D. F. Stroup, and J. L. Gerberding. 2004. Actual causes of death in the United States, 2000. Journal of the American Medical Association 291 (10): 1238-45. 
Nagi, S. Z. 1965. Some conceptual issues in disability and rehabilitation. In Sociology and rehabilitation, ed. M. B. Sussman, 100-13. Washington, DC: American Sociological Association.

Verbrugge, L. 1994. The disablement process. Social Science and Medicine 38 (1): $1-14$.

\section{Comment Anne Case}

This chapter provides an interesting quantification of the causes of the education gradient observed in disability in the U.S. elderly population. Using data from the Health and Retirement Study (HRS), the authors find that three factors can explain more than half of difference in disability found between high-school graduates and high-school dropouts: high school graduates were less likely to have worked in blue collar jobs during their working years, which may have protected them against wear and tear; they report better health behaviors, especially those related to smoking and obesity; and they are significantly less likely to report chronic conditions linked to disability. I found the chapter very interesting and thought provoking, and so my comments reflect thoughts on where this work might go from here.

\section{Difficulties in Quantifying Causal Effects of Education}

I think there is a fair amount of agreement that education is of firstorder importance in protecting health status. However, that said, there are real hurdles in ruling out "third factor" explanations for the associations found between higher levels of education and better health. For example, we know that children who are sickly generally complete fewer years of schooling. Persistence in health processes could then lead to a positive association between health and education in adulthood that is really attributable to the impact of poor health in childhood on both educational attainment and health in adulthood. Relatedly, if parents are themselves in poor health, this could lead to lower family socioeconomic status (SES) and both family SES and parents' health could lead to poorer schooling outcomes and poorer health for their children. We could have poorer health and lower educational attainment echoing down the generations, without having much with which to identify the size of the effects leading from health to education, and those leading from education to health. It is also possible that some individuals embody certain characteristics that could lead to both better education and better health. For example, more patient people may take the time to wash

Anne Case is the Alexander Stewart 1886 Professor of Economics and Public Affairs and a Professor of Economics and Public Affairs at the Woodrow Wilson School of Public and International Affairs and the Economics Department at Princeton University, and a research associate of the National Bureau of Economic Research. 